\title{
INHALT DES ERSTEN HALBJAHRESHEFTES
}

Nachruf auf Günter Poethke 1

\section{AUFSÄTZE}

Marco Perale, Critical Notes on Hexameter Adespota 5

Boris Kayachev, Variant readings in the so-called Tbilisi hymn

to Dionysus 43

Salvatore Costanza e Amphilochios Papathomas, P. Ross.Georg.

I 21: riedizione e commento del più esteso manuale di ieroscopia ......50

Nikolaos Gonis, A Tax Register from Roman Fayum............................. 85

Nikolaos Gonis, Prosopographica IV ................................................... 90

Carlos Sánchez Moreno Ellart, Die fictio legis Corneliae in P.Berol. 11753 A + 21294 A ..... 102

Frederic Krueger, The Monastery of Apa Posidonios at Hermonthis and an Alleged Local Cult of "Poseidon" (with Notes on "Kothos" and the Supposed Fish-Cult at Latopolis)............................................. 110

Robert K. Ritner, The God Kothos ..................................................... 138

Francesca Maltomini, Tea Ghigo, Oliver Hahn, and Ira Rabin, Florentine papyri under examination: the material study of the inks used at the beginning of the Common Era in the

"Family of Kôm Kâssûm" Archive (Hermopolis) ................................ 146

Holger Essler, Zur Entstehung der Hamburger Papyrussammlung ....... 166

\section{REFERATE}

\section{Darstellungen und Hilfsmittel}

Federico Morelli, I prezzi dei materiali e prodotti artigianali nei documenti tardoantichi e del primo periodo arabo (IV ex.-VIII d.C.). MPER N.S XXXIII, Berlin/Boston: De Gruyter 2019 (Lajos Berkes) 209

Thomas Kruse, Urkundenreferat 2015 (2. Teil) …................................. 213

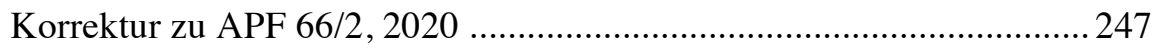

